\title{
Tryptase-positive mast cells correlate with angiogenesis in early breast cancer patients
}

\author{
GIROLAMO RANIERI ${ }^{1,8}$, MICHELE AMMENDOLA $^{2}$, ROSA PATRUNO $^{3}$, \\ GIUSEPPE CELANO ${ }^{3}$, FRANCESCO ALFREDO ZITO ${ }^{4}$, SEVERINO MONTEMURRO ${ }^{5}$, \\ ADDOLORATA RELLA ${ }^{6}$, VALENTINA DI LECCE ${ }^{4}$, COSMO DAMIANO GADALETA ${ }^{1}$, \\ GIOVANNI BATTISTA DE SARRO ${ }^{2}$ and DOMENICO RIBATTI ${ }^{7}$
}

${ }^{1}$ Interventional Radiology Unit, Department of Critical Area and Surgery, National Cancer Institute Giovanni Paolo II of Bari; ${ }^{2}$ Clinical Pharmacology Unit, University Magna Graecia of Catanzaro Medical School, Catanzaro; ${ }^{3}$ Pathology Laborathory, University of Bari; ${ }^{4}$ Pathology Unit and ${ }^{5}$ Department of Surgical Oncology, National Cancer Institute Giovanni Paolo II of Bari; ${ }^{6}$ Gynaecological Unit, USL BA $3 ; ;{ }^{7}$ Department of Human Anatomy and Histology, University of Bari Medical School; ${ }^{8}$ Department of Experimental Oncology, National Cancer Institute Giovanni Paolo II of Bari, Bari, Italy

Received November 25, 2008; Accepted January 25, 2009

DOI: 10.3892/ijo_00000319

\begin{abstract}
Literature data indicate that mast cells (MCs) are involved in tumor angiogenesis due to the release of several pro-angiogenetic factors among which tryptase, a serine protease stored in MCs granules, is one of the most active. However, no data are available concerning the role of MCs in angiogenesis in primary human breast cancer. In this study, we have evaluated the correlations between the number of MCs positive to tryptase (MCDPT), the area occupied by MCs positive to tryptase (MCAPT) and microvascular density (MVD) and endothelial area (EA) in a series of 88 primary T1-3, N0-2 M0 female breast cancer, by means of immunohistochemistry and image analysis methods. Data demonstrated a significant $(r=$ from 0.78 to 0.89 ; p-value from 0.001 to 0.002 by Pearson's analysis respectively) correlation between MCDPT, MCAPT, MVD, EA to each other. No correlation concerning MCDPT, MCAPT, MVD, EA and the main clinicopathological features was found. Our results suggest that tryptase-positive MCs play a role in breast cancer angiogenesis. In this context several tryptase inhibitors such as gabexate mesilate and nafamostat mesilate might be evaluated in clinical trials as a new anti-angiogenetic approach.
\end{abstract}

Correspondence to: Dr Girolamo Ranieri, National Cancer Institute Giovanni Paolo II, Via Hanhemann n. 10, 70126 Bari, Italy

E-mail: giroran@tiscalinet.it

Key words: tryptase, mast cells, angiogenesis, breast cancer, microvascular density, endothelial area

\section{Introduction}

Angiogenesis plays a crucial role in tumor growth in situ and at distance and is a well established anti-tumor target (1-4). Mast cells (MCs) intervene in tumor angiogenesis (5-7), throughout several classical pro-angiogenic factors such vascular endothelial growth factor (VEGF), fibroblast growth factor-2 (FGF-2), platelet-derived growth factor (PDGF), interleukin-6 (IL-6), and non classical pro-angiogenic factor, such as tryptase and chymase, stored in their secretory granules (8-11).

Data from experimental tumor models suggest that MCs accumulate near to tumor cells before the onset of angiogenesis and that they are required for macroscopic expansion and metastatic spread of primary tumor cells $(12,13)$. Evidence for a specific role for MCs has been reported in animal and human cancers, such as mast cell tumors, head and neck, gastric, lung and cutaneous malignancies, where MCs density is highly correlated with the extent of tumor angiogenesis (14-18).

In benign breast lesions and in primary breast cancer, tryptase-positive MCs are more numerous as compared to chymase-positive MCs (19). Recently, it has been demonstrated that tryptase-positive MCs are involved in angiogenesis in sentinel lymph nodes with micrometastases from patients with breast cancer (20). However no data have been published regarding the correlations between MCs positive to tryptase and angiogenesis in primary breast cancer tissue.

In the present study, we have evaluated the correlations between the number of MCs positive to tryptase (MCDPT), the area occupied by MCs positive to tryptase (MCAPT), microvascular density (MVD) and endothelial area (EA) in a series of primary T1-3, N0-2 M0 female breast cancer, by means of immunohistochemistry and image analysis methods. 
Table I. MCDPT, MCAPT, MVD and EA expression as a function of clinicopathological characteristics in a series of 88 breast cancer patients.

\begin{tabular}{|c|c|c|c|c|c|}
\hline Variable & $\begin{array}{l}\text { No. of } \\
\text { patients }\end{array}$ & $\begin{array}{l}\text { No. of tumors with } \\
\text { high } \operatorname{MCDPT}^{\mathrm{a}}(\%)\end{array}$ & $\begin{array}{l}\text { No. of tumors with } \\
\text { high } \mathrm{MCAPT}^{\mathrm{b}}(\%)\end{array}$ & $\begin{array}{l}\text { No. of tumors with } \\
\text { high } \mathrm{MVD}^{\mathrm{c}}(\%)\end{array}$ & $\begin{array}{c}\text { No. of tumors } \\
\text { with high } \mathrm{EA}^{\mathrm{d}}(\%)\end{array}$ \\
\hline \multicolumn{6}{|l|}{ Age (years) } \\
\hline Range $26-85$ & 88 & & & & \\
\hline Median 58 & 88 & & & & \\
\hline$<58$ years & 41 & $22(54)$ & $23(56)$ & $21(51)$ & $20(49)$ \\
\hline$\geq 58$ years & 47 & $24(51)$ & $25(53)$ & $23(49)$ & $22(47)$ \\
\hline \multicolumn{6}{|l|}{ Menopausal status } \\
\hline Premenopausal & 34 & $17(50)$ & $18(53)$ & $18(53)$ & $19(56)$ \\
\hline Postmenopausal & 54 & $29(54)$ & $30(56)$ & $28(52)$ & $28(52)$ \\
\hline \multicolumn{6}{|l|}{ Histological type } \\
\hline Ductal & 65 & $33(51)$ & $33(51)$ & $31(48)$ & $30(46)$ \\
\hline Lobular & 23 & $12(52)$ & $11(48)$ & $11(48)$ & $11(48)$ \\
\hline \multicolumn{6}{|l|}{ Tumor size } \\
\hline $\mathrm{pT}_{1}$ & 39 & $22(56)$ & $23(59)$ & $21(54)$ & $19(49)$ \\
\hline $\mathrm{pT}_{2}$ & 31 & $16(51)$ & $17(55)$ & $15(48)$ & $15(48)$ \\
\hline $\mathrm{pT}_{3}$ & 18 & $9(50)$ & $9(50)$ & $8(44)$ & $8(44)$ \\
\hline \multicolumn{6}{|l|}{ Nodal status } \\
\hline $\mathrm{pN}_{0}$ & 37 & $19(51)$ & $17(46)$ & $18(49)$ & $20(54)$ \\
\hline $\mathrm{pN}_{1-2}$ & 51 & $26(51)$ & $28(55)$ & $27(53)$ & $25(49)$ \\
\hline \multicolumn{6}{|c|}{ Cytohistological grade } \\
\hline $\mathrm{G}_{1}$ & 31 & $17(55)$ & $18(58)$ & $16(52)$ & $15(48)$ \\
\hline $\mathrm{G}_{2}$ & 37 & $19(51)$ & $21(57)$ & $20(54)$ & $19(51)$ \\
\hline $\mathrm{G}_{3}$ & 20 & $10(50)$ & $11(55)$ & $9(45)$ & $9(45)$ \\
\hline \multicolumn{6}{|c|}{ Estrogen receptor status } \\
\hline Negative & 27 & $16(59)$ & $16(59)$ & $15(56)$ & $14(52)$ \\
\hline Positive & 61 & $31(51)$ & $33(54)$ & $33(54)$ & $35(57)$ \\
\hline \multicolumn{6}{|c|}{ Progesterone receptor status } \\
\hline Negative & 32 & $15(47)$ & $16(50)$ & $14(44)$ & $14(44)$ \\
\hline Positive & 56 & $31(55)$ & $30(54)$ & $29(52)$ & $27(48)$ \\
\hline \multicolumn{6}{|l|}{ c-erbB-2 } \\
\hline Negative & 53 & $29(55)$ & $30(57)$ & $28(53)$ & $29(55)$ \\
\hline Positive & 35 & $17(49)$ & $18(51)$ & $16(46)$ & $16(46)$ \\
\hline
\end{tabular}

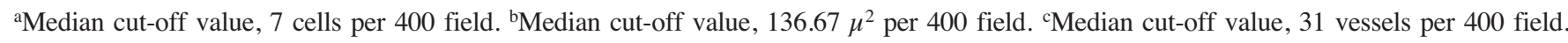
${ }^{\mathrm{d}}$ Median cut-off value, $146.54 \mu^{2}$ per 400 field.

\section{Patients and methods}

Patients. The clinicopathological features of the patients are summarized in the Table I. Biopsy specimens were collected from 88 female breast cancer patients who had undergone breast cancer surgery, classified accordingly the presence of a primary, invasive breast tumor (stage T1-T3), the presence or not of metastases in axillary lymph nodes (stage N0-N2), the absence of distant metastases (M0), the presence of unilateral breast cancer and the absence of previous or concomitant primary cancer. Patients were staged according to the International Union Against Cancer Tumor Node Metastasis (UICC-TNM) classification. Patients had not received neo-adjuvant therapies, they were subjected to a modified radical mastectomy (37 patients in which the tumor had a diameter $>3 \mathrm{~cm}$ ) or to a quadrantectomy followed by 5-6 weeks of radiation therapy (51 patients) and axillary lymph nodes were surgically removed when sentinel lymph node were positive. On the basis of clinicopathological features patients were then evaluated to receive adjuvant hormonal therapy or chemo-therapy or both.

Immunohistochemistry. The histological diagnosis was made on haematoxylin-eosin-stained slides and histopathological grading was performed according to the criteria described by Bloom and Richardson, as well, moderately and poorly differentiated state (21). 

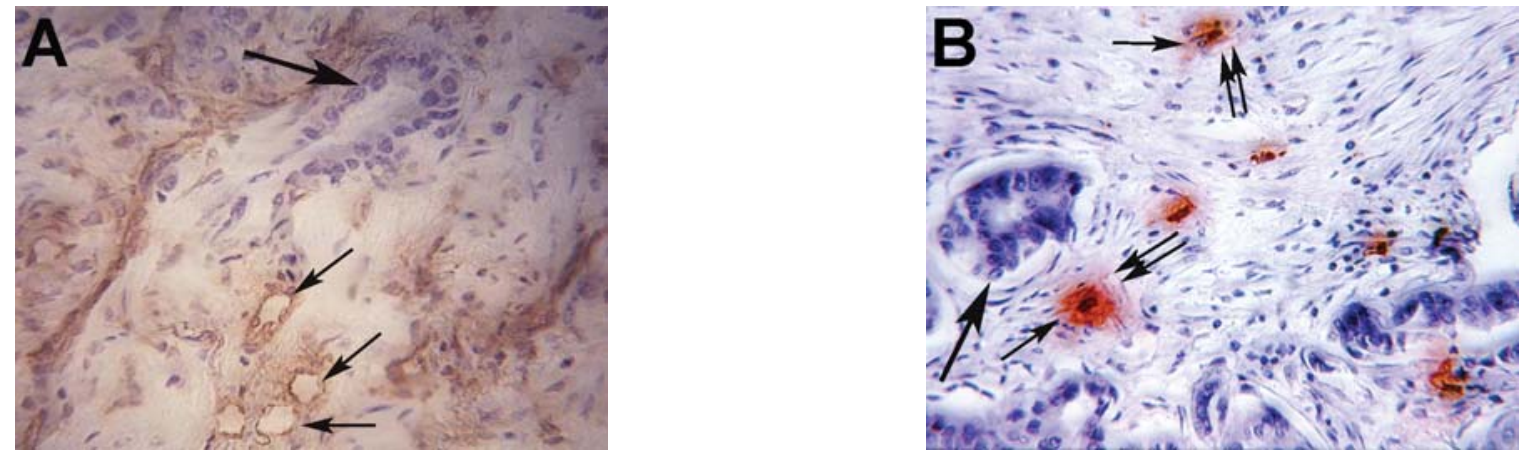

Figure 1. (A) A highly vascularized breast cancer sample stained with an anti-CD-34 antibody. Big arrow indicates ductal breast cancer cells, whereas small arrows indicate a single brown stained microvessel. (B) A breast cancer sample stained with an anti-tryptase antibody. Big arrow indicates ductal breast cancer cells, single small arrows indicate tryptase-positive mast cells and double small arrows indicate adjacent microvessels. Magnification: A and B, x400.
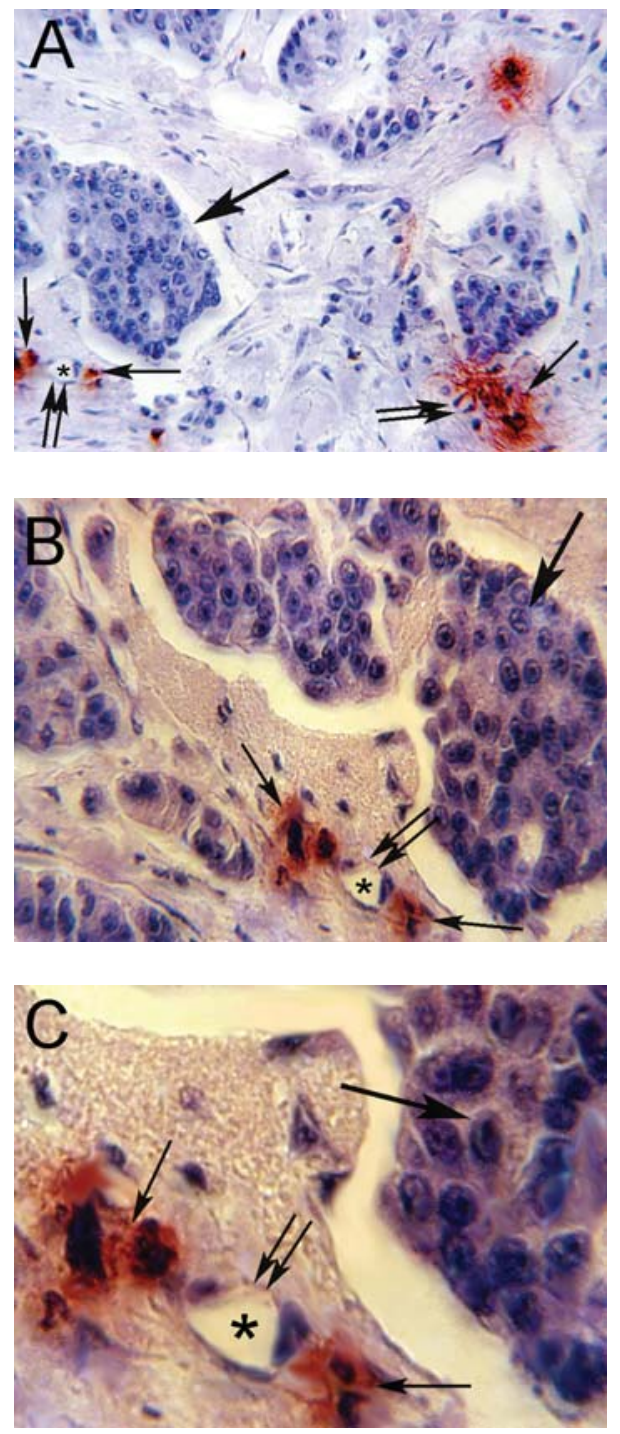

Figure 2. Breast cancer sample stained with an anti-tryptase antibody. (A) A big arrow indicates breast cancer cells, single small arrows indicate tryptasepositive mast cells and double small arrows indicate adjacent microvessel with an asterisk in its lumen. (B) A particular of the same section at an higher magnification, where big arrow indicates breast cancer cells, single small arrows indicate tryptase-positive mast cells and double small arrows indicate the adjacent microvessel with an asterisk in its lumen. (C) A particular of the same section at an higher magnification, where a big arrow indicates breast cancer cells, single small arrows indicates red tryptase-positive mast cells and double small arrows indicate the adjacent microvessels with an asterisk in its lumen. Original magnification: A, x250; B, x600; C, x1000.
For the evaluation of MCDPT, MCAPT, MVD and EA, a three layer biotin-avidin-peroxidase system was utilized, as previously described (22). Briefly, six-micrometer thick serial sections of formalin-fixed and paraffin-embedded biopsy tumor samples were deparaffinized. Then, for antigen retrieval, sections were microwaved at $500 \mathrm{~W}$ for $10 \mathrm{~min}$, after which endogenous peroxidase activity was blocked with $3 \%$ hydrogen peroxide solution. Next, slides were incubated with human-specific monoclonal antibodies anti-CD34 (QB-END 10; Bio-Optica Milan, Italy) diluted 1:50 for $1 \mathrm{~h}$ at room temperature and anti-tryptase (clone AA1; Dako, Glostrup, Denmark) diluted 1:100 for $1 \mathrm{~h}$ at room temperature. The bound antibody was visualised using biotinylated secondary antibody, avidin-biotin peroxidase complex and and 3amino-9-ethylcarbazole or 3,3 diaminobenzidine. Nuclear counterstaining was performed with Gill's haematoxylin no. 2 (Polysciences, Warrington, PA, USA). Primary antibody was omitted in negative controls.

Morphometrical assay. An image analysis system (Quantimet 500 Leica, Wetzlar, Germany) was utilized. The five most vascularized areas ('hot spot') were selected at low magnification and both individual vessels (Fig. 1A) and MCs (Fig. 1B) were counted at x400 magnification (15). Single brown stained endothelial cells, endothelial cell clusters and microvessels, clearly separated from adjacent microvessels, tumor cells and other connective tissue elements were counted (22). Areas of necrosis were not considered for counting. In serial sections each single tryptase-positive MC was counted. Single brown stained endothelial cells and red MCs positive to tryptase were also evaluated in terms of immunostained area at x400 magnification (22).

Statistical analysis. MCDPT, MCAPT, MVD, EA mean values \pm 1 standard deviations (SD) were evaluated by two independent observers (G.R. and F.A.Z.) for each tumor sample and in all series of sections. Correlations between MCDPT, MCAPT, MVD and EA to each other were calculated using Pearson's (r) analysis. The correlations between the above indexes and the clinicopathological features listed in Table I were analyzed by Chi-square test. All statistical analysis were performed with the SPSS statistical software package (SPSS, Inc., Chicago, IL). 

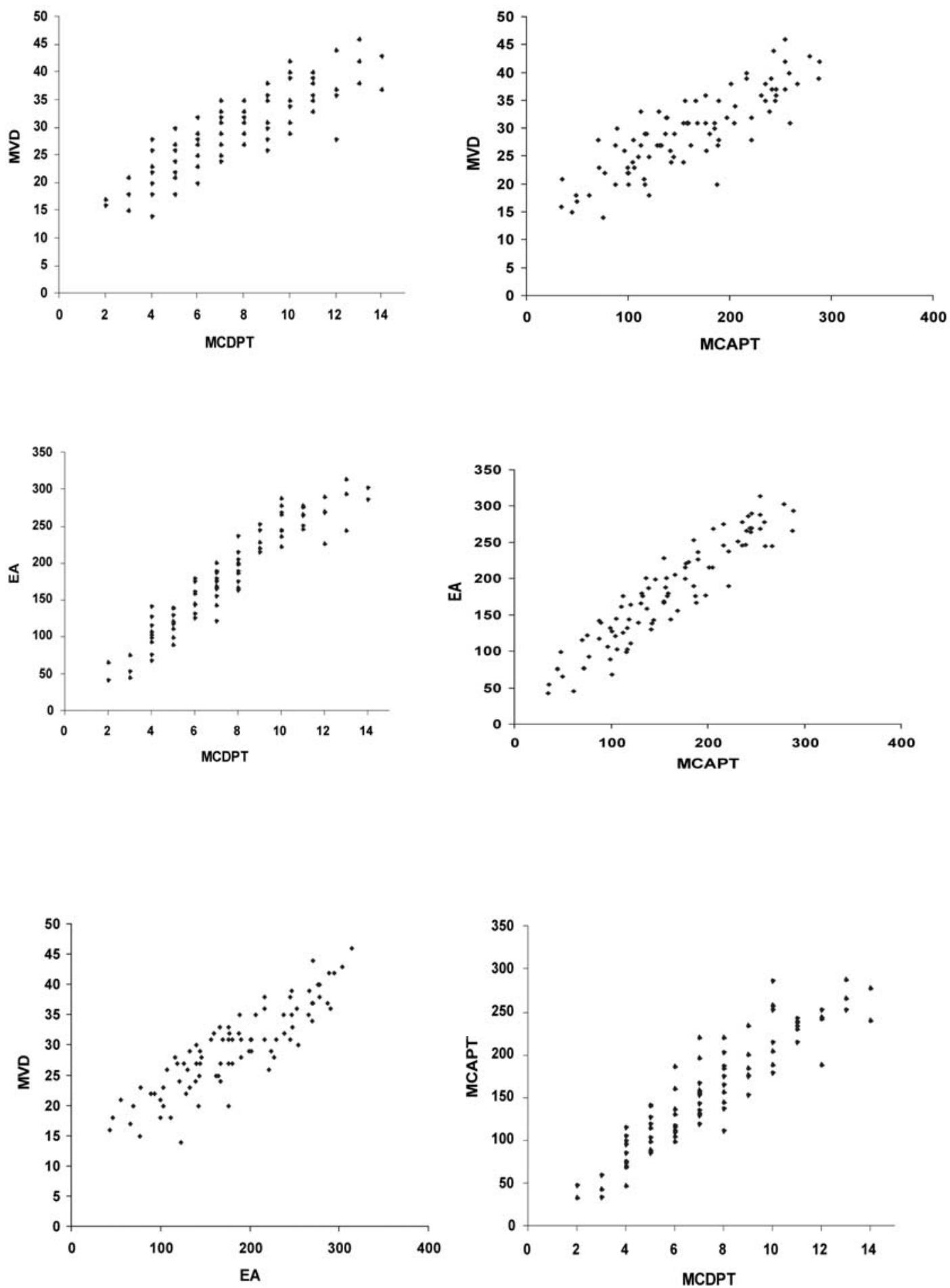

Figure 3. Correlation analysis between MCDPT and MVD ( $\mathrm{r}=0.83$, $\mathrm{p}=0.001)$; MCAPT and MVD ( $\mathrm{r}=0.80, \mathrm{p}=0.001)$; MCDPT and EA ( $\mathrm{r}=0.86$, $\mathrm{p}=0.001$ ); MCAPT and EA ( $r=0.81 ; \mathrm{p}=0.001)$; MVD and EA ( $r=0.88 ; \mathrm{p}=0.001)$; MCDPT and MCAPT $(\mathrm{r}=0.75, \mathrm{p}=0.002)$.

Table II. MCDPT, MCAPT, MVD and EA means \pm 1 standard deviations in a series of 88 breast cancer patients.

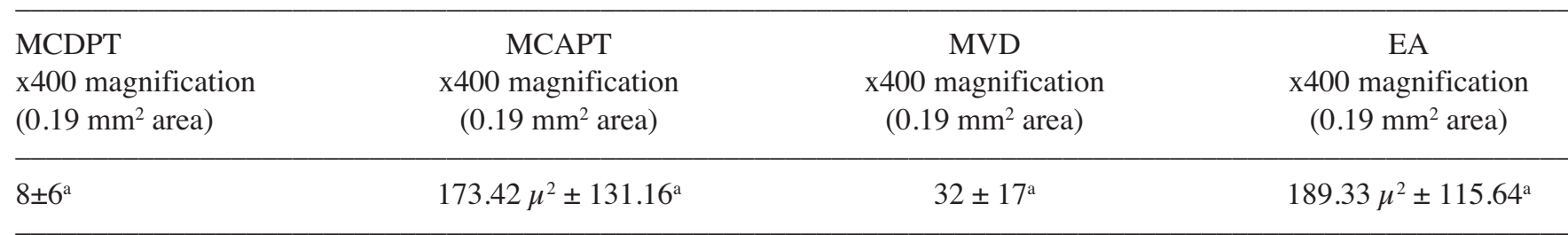

${ }^{a}$ Mean \pm 1 standard deviation. 


\section{Results}

Immunohistochemical staining by using the antibodies antiCD34 and anti-tryptase allow to demonstrate that in highly vascularized breast cancer tissue tryptase-positive MCs are well recognizable and generally they are located in perivascular position (Figs. 1 and 2).

Mean values $\pm 1 \mathrm{SD}$ of all the evaluated parameters are listed in Table II. There was a significant correlation between MCDPT and MVD ( $\mathrm{r}=0.83, \mathrm{p}=0.001)$, between MCAPT and MVD ( $r=0.80, p=0.001)$, between MCDPT and EA ( $r=0.86$, $\mathrm{p}=0.001)$, between MCAPT and EA $(\mathrm{r}=0.81 ; \mathrm{p}=0.001)$, between MVD and EA $(r=0.88 ; \mathrm{p}=0.001)$ and between MCDPT and MCAPT ( $r=0.75, p=0.002)$ (Fig. 3). No correlation concerning MCDPT, MCAPT, MVD, EA and the main clinicopathological features was found.

\section{Discussion}

In this study, for the first time, we found in a series of 88 primary T1-3, N0-2 M0 female breast cancer, that the number of MCs positive to tryptase (MCDPT), the area occupied by MCs positive to tryptase (MCAPT), microvascular density (MVD) and endothelial area (EA) correlate to each other.

Tryptase is one of the most powerful angiogenic mediators released by human MCs and it may be angiogenic via several mechanisms (23-26). Blair et al have demonstrated that direct addition of tryptase to microvascular endothelial cells cultured on Matrigel caused a pronounced increase of capillary growth, which was suppressed by specific tryptase inhibitors, and directly induced endothelial cell proliferation in a dose-dependent fashion (10). Tryptase is involved in tissue remodelling and it may also act indirectly on tissue neovascularization by releasing latent angiogenetic factors bound to the extracellular matrix (27). Tryptase is an agonist of the proteinase-activated receptor-2 (PAR-2) in vascular endothelial cells and breast cancer cells (28-33). Activation of PAR-2 induce cell proliferation and release of IL-6 and granulocyte-macrophage colony stimulating factor (GM-CSF), which, in turn, act as angiogenic molecules (34).

It has been previously demonstrated that in several types of malignancies such as multiple myeloma, oral squamous cancer, melanoma, gastrointestinal cancer and lung cancer there is a correlation between tryptase-positive MCs and microvessel counts and both increase in function of malignancy $(7,14-18,35-38)$. Accordingly, in this study we have demonstrated that also in breast cancer tissue there is a strong association between the number of MCs positive to tryptase and MVD. When we evaluated MCs positive to tryptase and angiogenesis in terms of morphometrical parameters we showed a strong association between the area occupied by MCs positive to tryptase and the area occupied by immunostained endothelial cells in terms of morphometrical angiogenesis. Interestingly tryptase positivity is observed near or around microvessels with a small evident lumen. Taken together these data suggest that MCs positive to tryptase may play a role in primary breast cancer angiogenesis, but they are not correlated with the main clinicopathological features (39). In this context several tryptase inhibitors such as gabexate mesilate and nafamostat mesilate $(40,41)$ might be tested in clinical trials as a new anti-angiogenetic approach.

\section{Acknowledgements}

This study was supported in part by grants from Alleanza Contro il Cancro - Istituto Superiore di Sanità, Italy.

\section{References}

1. Fisseler-Eckhoff A, Rothstein D and Muller KM: Neovascularisation in hyperplastic, metaplastic and potentially preneoplastic lesions of the bronchial mucosa. Virchows Arch 429: 95-100, 1996.

2. Folkman J: Tumor angiogenesis and tissue factor. Nat Med 2: 209-215, 1996.

3. Gasparini G, Brooks PC, Biganzoli E, Vermeulen PB, Bonoldi E, Dirix LY, Ranieri G, Miceli R and Cheresh DA: Vascular integrin alpha (v) beta3: a new prognostic indicator in breast cancer. Clin Cancer Res 4: 2625-2634, 1998 .

4. Ranieri G, Patruno R, Ruggieri E, Montemurro S, Valerio P and Ribatti D: Vascular endothelial growth factor (VEGF) as a target of bevacizumab in cancer: from the biology to the clinic. Curr Med Chem 13: 1845-1857, 2006.

5. Patruno R, Arpaia N, Gadaleta CD, Passantino L, Zizzo N, Misino A, Lucarelli NM, Catino A, Valerio P, Ribatti D and Ranieri G: VEGF concentration from plasma activated platelets rich correlates with microvascular density and grading in canine mast cell tumour spontaneous model. J Cell Mol Med (In press).

6. Soucek L, Lawlor ER, Soto D, Shchors K, Swigart LB and Evan GI: Mast cells are required for angiogenesis and macroscopic expansion of Myc-induced pancreatic islet tumors. Nat Med 13: 1211-1218, 2007.

7. Ribatti D, Vacca A, Nico B, Quondamatteo F, Ria R, Minischetti M, Marzullo A, Herken R, Roncali L and Dammacco F: Bone marrow angiogenesis and mast cell density increase simultaneously with progression of human multiple myeloma. Br J Cancer 79: 451-455, 1999.

8. Norrby K: Mast cells and angiogenesis. APMIS 110: 355-371, 2002.

9. Kankkunen JP, Harvima IT and Naukkarinen A: Quantitative analysis of tryptase and chymase containing mast cells in benign and malignant breast lesions. Int J Cancer 72: 385-388, 1997.

10. Blair RJ, Meng H, Marchese MJ, Ren S, Schwartz LB, Tonnesen MG and Gruber BL: Human mast cells stimulate vascular tube formation. Tryptase is a novel, potent angiogenic factor. J Clin Invest 99: 2691-2700, 1997.

11. Somasundaran P, Ren G, Nagar H, Kraemer D, Mendoza L, Michael LH Caughey GH, Entman ML and Frangogiannis NG: Mast cell tryptase may modulate endothelial cell phenotype in healing myocardial infarcts. J Pathol 205: 102-111, 2005.

12. Polverini PF: How the extracellular matrix and macrophages contribute to angiogenesis-dependent disease. Eur J Cancer 32A: 2430-2437, 1996 .

13. Dethlefsen SM, Matsuura N and Zetter BR: Mast cell accumulation at sites of murine tumor implantation: implications for angiogenesis and tumor metastasis. Invasion Metastasis 14: 395-408, 1994.

14. Ranieri G, Passantino L, Patruno R, Passantino G, Jirillo F, Catino A, Mattioli V, Gadaleta C and Ribatti D: The dog mast cell tumour as a model to study the relationship between angiogenesis, mast cell density and tumour malignancy. Oncol Rep 10: 1189-1193, 2003.

15. Ranieri G, Labriola A, Achille G, Florio G, Zito AF Grammatica L and Paradiso A: Microvessel density, mast cell density and thymidine phosphorylase expression in oral squamous carcinoma. Int J Oncol 21: 1317-1323, 2002.

16. Yano H, Kinuta M, Tateishi H, Nakano Y, Matsui S, Monden T, Okamura J, Sakai M and Okamoto S: Mast cell infiltration around gastric cancer cells correlates with tumor angiogenesis and metastasis. Gastric Cancer 2: 26-32, 1999.

17. Takanami I, Takeuchi $\mathrm{K}$ and Naruke M: Mast cell density is associated with angiogenesis and poor prognosis in pulmonary adenocarcinoma. Cancer 88: 2686-2692, 2000.

18. Ch'ng S, Wallis RA, Yuan L, Davis PF and Tan ST: Mast cells and cutaneous malignancies. Mod Pathol 19: 149-159, 2006. 
19. Kashiwase Y, Morioka J, Inamura H, Yoshizawa Y, Usui R and Kurosawa M: Quantitative analysis of mast cells in benign and malignant breast lesions. Immunohistochemical study on formalin-fixed, paraffin-embedded tissues. Int Arch Allergy Immunol 134: 199-205, 2004

20. Ribatti D, Finato N, Crivellato E, Guidolin D, Longo V Mangieri D, Nico B, Vacca A and Beltrami CA: Angiogenesis and mast cells in human breast cancer sentinel lymph nodes with and without micrometastases. Histopathology 51: 837-842, 2007.

21. Bloom HJ and Richardson WW: Histological grading and prognosis in breast cancer; a study of 1409 cases of which 359 have been followed for 15 years. Br J Cancer 11: 359-377, 1957.

22. Ranieri G, Grammatica L, Patruno R, Zito AF, Valerio P, Iacobellis S, Gadaleta C, Gasparini G and Ribatti D: A possible role of thymidine phosphorylase expression and 5-fluorouracil increased sensitivity in oropharyngeal cancer patients. J Cell Mol Med 11: 362-368, 2007.

23. Coussens LM, Raymond WW, Bergers G, Laig-Webster M, Behrendtsen O, Werb Z, Werb Z, Caughey GH and Hanahan D: Inflammatory mast cells up-regulate angiogenesis during squamous epithelial carcinogenesis. Genes Dev 13: 1382-1397, 1999

24. Nico B, Mangieri D, Crivellato E, Vacca A and Ribatti D: Mast cells contribute to vasculogenic mimicry in multiple myeloma. Stem Cells Dev 17: 19-22, 2008.

25. Ribatti D, Nico B, Maxia C, Longo V, Murtas D, Mangieri D, Perra MT, De Giorgis M, Piras F, Crivellato E and Sirigu P: Neovascularization and mast cells with tryptase activity increase simultaneously in human pterygium. J Cell Mol Med 11: 585-589, 2007.

26. Hallgren J, Estrada S, Karlson U, Alving K and Pejler G: Heparin antagonists are potent inhibitors of mast cell tryptase. Biochemistry 40: 7342-7439, 2001.

27. Fajardo I and Pejler G: Human mast cell beta-tryptase is a gelatinase. J Immunol 171: 1493-1499, 2003.

28. Itoh Y, Sendo T and Oishi R: Physiology and pathophysiology of proteinase-activated receptors (PARs): role of tryptase/PAR-2 in vascular endothelial barrier function. J Pharmacol Sci 97: $14-19,2005$

29. Shpacovitch VM, Brzoska T, Buddenkotte J, Stroh C, Sommerhoff CP, Ansel JC, Schulze-Osthoff K, Bunnett NW, Luger TA and Steinhoff M: Agonists of proteinase-activated receptor 2 induce cytokine release and activation of nuclear transcription factor kappaB in human dermal microvascular endothelial cells. J Invest Dermatol 118: 380-385, 2002.

30. Rickard A, Portell C, Kell PJ, Vinson SM and McHowat J: Protease-activated receptor stimulation activates a $\mathrm{Ca}^{2+}$-independent phospholipase A2 in bladder microvascular endothelial cells. Am J Physiol Renal Physiol 288: F714-F721, 2005.
31. Sendo T, Sumimura T, Itoh Y, Goromaru T, Aki K, Yano T, Oike M, Ito Y, Mori S, Nishibori M and Oishi R: Involvement of proteinase-activated receptor-2 in mast cell tryptase-induced barrier dysfunction in bovine aortic endothelial cells. Cell Signal 15: 773-781, 2003

32. Matej $\mathrm{R}$, Mandàkovà $\mathrm{P}$, Netikovà $\mathrm{I}$, Pouckovà $\mathrm{P}$ and Olejàr $\mathrm{T}$ : Proteinase-activated receptor-2 expression in breast cancer and the role of trypsin on growth and metabolism of breast cancer cell line MDA MB-231. Physiol Res 56: 475-484, 2007.

33. Morris DR, Ding Y, Ricks TK, Gullapalli A, Wolfe BL and Trejo J: Protease-activated receptor-2 is essential for factor VIIa and Xa-induced signaling, migration, and invasion of breast cancer cells. Cancer Res 66: 307-314, 2006.

34. Liu Y and Mueller BM: Protease-activated receptor-2 regulates vascular endothelial growth factor expression in MDA-MB-231 cells via MAPK pathways. Biochem Biophys Res Commun 344: 1263-1270, 2006

35. Ribatti D, Ennas MG, Vacca A, Ferreli F, Nico B, Orru S and Sirigu P: Tumor vascularity and tryptase-positive mast cells correlate with a poor prognosis in melanoma. Eur J Clin Invest 33: 420-425, 2003.

36. Yodavudh S, Tangjitgamol S and Puangsa-art S: Prognostic significance of microvessel density and mast cell density for the survival of Thai patients with primary colorectal cancer. J Med Assoc Thai 91: 723-732, 2008.

37. Ibaraki T, Muramatsu M, Takai S, Jin D, Maruyama H, Orino T, Katsumata $\mathrm{T}$ and Miyazaki M: The relationship of tryptase- and chymase-positive mast cells to angiogenesis in stage I non-small cell lung cancer. Eur J Cardiothorac Surg 28: 617-621, 2005.

38. Peng SH, Deng H, Yang JF, Xie PP, Li C, Li H and Feng DY: Significance and relationship between infiltrating inflammatory cell and tumor angiogenesis in hepatocellular carcinoma tissues. World J Gastroenterol 11: 6521-6524, 2005.

39. Goldhirsch A, Wood WC, Gelber RD, Coates AS, Thürlimann B and Senn HJ: 10th St. Gallen conference. Progress and promise: highlights of the international expert consensus on the primary therapy of early breast cancer. Ann Oncol 18: 1133-1144, 2007.

40. Erba F, Fiorucci L, Pascarella S, Menegatti E, Ascenzi P and Ascoli F: Selective inhibition of human mast cell tryptase by gabexate mesylate, an antiproteinase drug. Biochem Pharmacol 61: 271-276, 2001

41. Mori S, Itoh Y, Shinohata R, Sendo T, Oishi R and Nishibori M: Nafamostat mesilate is an extremely potent inhibitor of human tryptase. J Pharmacol Sci 92: 420-423, 2003. 